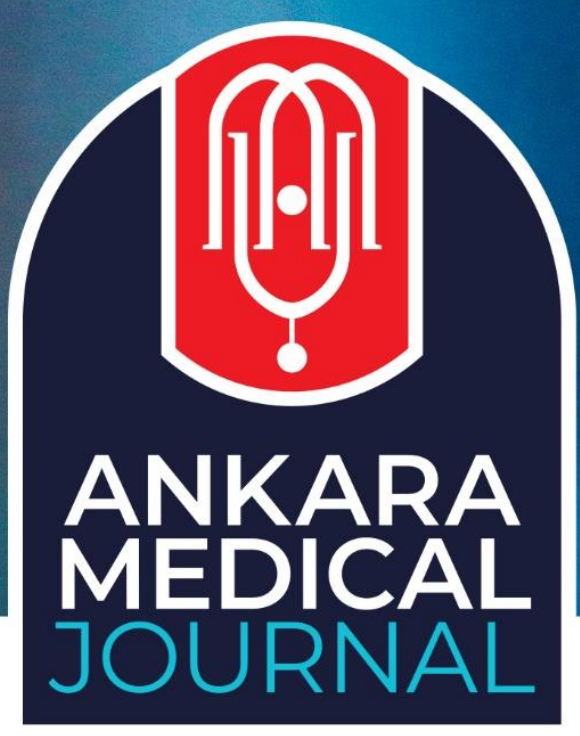

Research Article

Ankara Med J, 2020;(2):348-359 // (10) 10.5505/amj.2020.60343

\title{
FEARFUL EXPERIENCE OF WOMEN: MASTALGIA
}

\section{KADINLARIN KORKU DOLU DENEYIMII: MASTALJİ}

(D) Servet Kocaoz ${ }^{1}$, (D) Omer Parlak ${ }^{2}$

${ }^{1}$ Ankara Şehir Hastanesi, Genel Cerrahi Ana bilim Dalı, Bilkent, Ankara, Türkiye. ${ }^{2}$ Yıldırım Beyazıt Üniversitesi Tıp Fakültesi, Genel Cerrahi Ana bilim Dalı, Ankara, Türkiye.

Yazışma Adresi / Correspondence:

Servet Kocaöz (e-mail: servet.kocaoz@gmail.com)

Geliş Tarihi (Submitted): 15.02.2020 // Kabul Tarihi (Accepted): 27.05.2020

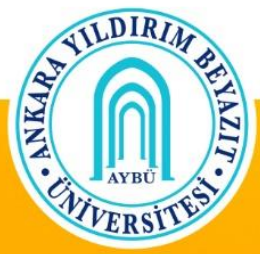

Ankara Yıldırım Beyazıt University Faculty of Medicine Department of Family Medicine 


\section{Öz}

Amaç: Mastalji en sık görülen meme yakınmasıdır. Bu çalışmanın amacı meme ağrısına neden olan faktörleri araştırmaktır.

Materyal ve Metot: Atatürk Eğitim ve Araștırma Hastanesi cerrahi polikliniğine meme rahatsızlı̆̆ı veya diğer şikayetler ile başvuran 18-65 yaşları arasında 159'u meme ağrısı olan ve 159'u meme ağrısı olmayan toplam 318 kadın 1 Aralık 2018 ve 31 Ocak 2019 tarihleri arasında çalışmaya dahil edildi. Bu hastalara meme ağrısına neden olduğu düşünülen faktörleri içeren bir değerlendirme anket uygulandı.

Bulgular: Meme ağrısı 50 yaş ve üstü hastalarda anlamlı olarak daha yüksek bulundu (OR = 3,496, \%95 GA: 3,496-11,056). Emziren kadınların emzirmeyen kadınlardan yaklaşık 3 kat daha fazla mastaljisi olduğu belirlendi (OR = 2,667, \%95 GA: 1,262-5,637). Mastalji prevalansının sigara içenlerde sigara içmeyenlere göre $2,5$ kat daha yüksek olduğu belirlendi ( $\mathrm{OR}=2,466, \% 95 \mathrm{GA}: 1,306-4,659)$. Alkol kullanan kadınlarda mastaljinin içmeyenlere göre 4,5 kat daha fazla olduğu görüldü (OR = 4,456, \%95 GA: 1,394-14,244). Kilo alan kadınlarda mastalji gelișme olasılığının kilo almayanlara göre yaklașık 2,5 kat daha fazla olduğu belirlendi $(\mathrm{OR}=2,593$, \%95 GA: 1,396-4,818). Ayrıca mastaljinin diğer benign meme rahatsızlıkları olan hastalarda 21 kat daha fazla geliştiği bulundu (OR = 20,996, \%95 GA: 10,344-42,620).

Sonuç: Bu çalışmada mastaljinin 50 yaş ve üstü kadınlarda daha sık görüldügüü, emzirme, iyi huylu meme hastalığı, sigara ve alkol tüketimi ve kilo almanın mastaljiye neden olan risk faktörleri olduğu ortaya konuldu. Anahtar Kelimeler: Mastalji, meme ağrısı, mastodini, risk faktörü, cerrahi.

\section{Abstract}

Objectives: Mastalgia is the most common breast complaint. The aim of this study is to investigate the factors that cause breast pain.

Materials and Methods: A total of 318 women between the ages of 18 to 65 with 159 having breast pain and 159 without breast pain who applied to the surgery outpatient clinic of Atatürk Training and Research Hospital with breast discomfort or other complaints December 1, 2018, and January 31, 2019, were included in the study. An assessment questionnaire, including the factors, thought to cause breast pain, was applied to these patients.

Results: Breast pain was found to be significantly higher in patients aged 50 years and older $(0 R=3.496,95 \%$ CI: 3.496-11.056). It was determined that breastfeeding women approximately three times more mastalgia than non-breastfeeding women (OR=2.667, 95\% CI: 1.262-5.637). It was determined that the prevalence of mastalgia was 2.5 times higher in smokers than in non-smokers (OR=2.466, 95\% CI: 1.306-4.659). It was found than mastalgia was 4.5 times higher in women that drink alcohol than in non-drinkers $(\mathrm{OR}=4.456,95 \% \mathrm{CI}$ : 1.394-14.244). It was determined that women who gained weight were approximately 2.5 times more likely to develop mastalgia than those without weight gain (OR=2.593, 95\% CI: 1.396-4.818). It was also found that mastalgia is 21 -fold more likely to develop in patients with other benign breast discomforts $(0 \mathrm{R}=20.996,95 \%$ CI: 10.344-42.620).

Conclusion: This study revealed that mastalgia was more common in women aged 50 years and older, breastfeeding, the presence of benign breast disease, cigarette, and alcohol consumption, and gaining weight are risk factors causing mastalgia.

Keywords: Mastalgia, breast pain, mastodynia, risk factor, surgery 


\section{Introduction}

Mastalgia is pain that is felt in the breast tissue. It is the most commonly seen breast complaint in women and experienced by $70 \%$ of all women throughout their lives. Although it is so common, only $15 \%$ require treatment.1,2 Mastalgia is most commonly seen in women aged 30-50. Breast pain can be divided into four categories; cyclic pain, non-cyclic pain, chest wall pain, and pain reflected from outside the chest wall. ${ }^{3}$ Cyclic mastalgia is related to the menstrual cycle and commonly seen in young women. It is felt before the menstruation in the upper outer quadrant of both breasts. This pain is common and spreads to the arm and armpits. ${ }^{4}$ Non-cyclic mastalgia is independent of the menstrual cycle. It is most commonly experienced between the ages of 40-50 and characterized by a sharp burning sensation. The pain is localized, mostly one-sided, and only felt in one quadrant of the breast. ${ }^{5}$ Chest wall pain is caused by skeletal and neurological pathologies outside the breast.6,7 Pain reflected from outside the chest wall is caused by cardiovascular and biliary pathologies. ${ }^{8}$ Cancer is rarely a reason for breast pain. Cancer-related breast pain is non-cyclic, one-sided and well localized and only seen in $0.2-0.5 \%$ of all mastalgia patients. ${ }^{9-11}$ Irregular menstrual cycles, the use of OCS, HRT, psychiatric drugs, some cardiovascular drugs, psychosocial factors, and depression may cause chest pain. ${ }^{12-14}$ Breast pain can also be caused by other factors such as smoking, excessive caffeine intake, excessive salt intake, obesity, alcohol consumption, pregnancy, mastitis, trauma, duct ectasia, macro cysts of the breast, and benign tumors. ${ }^{11,15} \mathrm{Also}$, having gained weight in the last five years and using bras that are too small or too big are also factors that can cause breast pain. ${ }^{15}$ When the patients who have no pathological findings after clinical examination and imaging are told that they do not have cancer, 78-85\% of women suffering from mastalgia are relieved. 4,16 Breast pain is felt differently by women, and methods of coping breast pain with it also vary. ${ }^{15}$ The aim of this study is to investigate the factors that cause breast pain.

\section{Materials and Methods}

A total of 318 women with 159 having breast pain and without 159 breast pain, between the ages of 18 to 65 , who applied to the surgery outpatient clinic of Atatürk Training and Research Hospital with breast discomfort or other complaints, were included in the study. Women who agreed to participate in this study were administered a questionnaire for breast pain assessment after completing the informed consent form. The study was carried out between December 1, 2018, and January 31, 2019. In addition to demographic and socioeconomic questions, 11 questions that were thought to be risk factors were asked in the present study.

In this case-control study, the sample size was determined by using G-power 3.1.9.4 version software. According to G-power analysis, the Chi-square test was used to compare the risk factors causing breast pain in 
women. This test was used to calculate the medium effect size $(d=0.5)$ and 95\% power level. As a result, it was calculated that a total of 318 women, of whom 159 had no chest pain, and 159 had no chest pain, should be included in the study.

In our study, those who are not within the age range of 18-65, those with a psychiatric disorder such as depression and anxiety disorder, suffering from physical or psychological trauma (such as traffic accident or loss of a relative), chronic illness, mental and physical disability, patients who refused to volunteer for the study were excluded.

After the approval of the ethics committee, women were administered a breast pain questionnaire. The language of the questionnaire was Turkish and was administered by a policlinic nurse. However, the questionnaire was administered to 10 women before the study, and necessary revisions were made. The survey regarding demographic and socioeconomic data questioned the patient's age, height, weight, educational status, marital status, and profession. In addition, she was asked about breastfeeding status if she had a baby. Also, the patients were asked if they used the birth control pill. It was asked if the presence of breast pain, its severity, its relationship to menstruation, and whether it affects daily life or not. In order to evaluate the severity of the patient's breast pain, a $10 \mathrm{~cm}$ scale (Visual Pain Scale) was used, which wrote pain on one end and the most severe pain on the other. In this ruler, the length of the distance from where there was no pain to the point marked by the patient was used to determine the pain of the patient. The patients were asked if they have a fear of breast cancer and if they want to receive education on breast cancer. Besides, whether were asked if they did know how to carry out a breast self-examination and if they want to be trained in the matter. It was also questioned if any of the risk factors for breast pain, such as tea and coffee consumption, cigarette use, alcohol consumption, salt consumption, weight gain, bra preference, lying on the breasts, taking a blow to the breasts. In addition, the patients were asked whether they had benign breast disease previously detected by imaging methods.

\section{Statistical analysis}

Data obtained from the study were loaded into SPSS and analyzed (version 25.0; SPSS, Chicago, IL, USA). Number, percentage, mean and standard deviation values were used to evaluate descriptive statistics. Differences in demographic and clinical features between the two groups were analyzed using Student's t-test for quantitative variables and chi-square tests for categorical variables. Risk factors for breast pain were evaluated with Multivariate Logistic Regression Analysis. For the backward model, inclusion criteria for analysis were accepted as 0.01 , exclusion criteria being 0.05 . Independent variables were included in the analysis by coding. 


\section{Results}

A total of 318 patients were surveyed. The patients' average age was recorded as 39.57 \pm 9.59 age (min. age: 19, median age: 39 , and max. age: 64). The average BMI of the patients was recorded as $27.70 \pm 5.24 \mathrm{~kg} / \mathrm{m} 2$ (min. BMI: 16.61, median BMI: 27.66, and max. BMI: 45.79). When the patients with and without breast pain were compared according to age, it was determined that the breast pain was significantly higher in women aged 3049 ( $\mathrm{p}=0.027$ ) (Table 1). A total of 43.4\% (69) of patients with breast pain reported that breast pain caused limitations to their daily activities. Again, 45.2\% (72) of patients with breast pain reported that they wake up from their sleep because of the pain. Of the patients with breast pain, 33 were in menopause. In the other patients, the breast pain was periodic (related to the menstrual cycle) in $48.41 \%$ (61) and non-periodic in $51.59 \%$ (65). Breast pain; women who married, unemployed, primary school graduate, gaining excess weight in the last 5 years, breastfeed for a long time, used OCS or HRT (with more than 6 months of use), detected with a mass in the breast examination and radiological imaging, not knowing how to perform breast selfexamination, that lies over their breasts, consume alcohol and smokers, significantly higher breast pain was determined than other women (Table 2-3). Pain scores (VAS score) of patients with mastalgia complaints were found to be $4.91 \pm 2.11$. The effect of risk factors on mastalgia was evaluated in Multivariate Logistic Regression Analysis. In the presence of other variables, it was found that women 50 years and older were 3.5 times more likely to develop mastalgia than women aged 29 years and under (OR=3.496, 95\% CI: 3.496-11.056) (Table4). It was determined that breastfeeding women developed approximately 3 times more mastalgia than nonbreastfeeding women (OR=2.667, 95\% CI: 1.262-5.637). There is a 0.212 -fold increase in the probability of mastalgia in short-term users of OCS compared to non-OCS users (OR=0.212, CI: 0.101-0.445). It was determined that mastalgia developed 0.164 times more in patients users OCS compared to those not using OCS $(\mathrm{OR}=0.164,95 \% \mathrm{CI}: 0.060-0.444)$. It was determined that the prevalence of mastalgia was 2.5 times higher in smokers than in non-smokers (OR=2.466, 95\% CI: 1.306-4.659). It was found that the prevalence of mastalgia was 4.5 times higher in women that drink alcohol than in non-drinkers (OR=4.456, 95\% CI: 1.394-14.244). It was determined that women who gained weight were approximately 2.5 times more likely to develop mastalgia than those without weight gain (OR=2.593, 95\% CI: 1.396-4.818). It was also found that mastalgia is 21 -fold more likely to develop in patients with other benign breast discomforts (OR=20.996, 95\% CI: 10.344-42.620). 
Table 1. Distribution of sociodemographic characteristics according to groups with and without mastalgia

\begin{tabular}{|c|c|c|c|c|c|}
\hline \multirow{2}{*}{ Risk Factors } & \multicolumn{2}{|c|}{ with mastalgia } & \multicolumn{2}{|c|}{ without mastalgia } & \multirow{2}{*}{ Test $/ p$} \\
\hline & $\mathbf{n}$ & $\%$ & $\mathbf{n}$ & $\%$ & \\
\hline \multicolumn{6}{|l|}{ Age group } \\
\hline aged $\leq 29$ & 32 & 64.00 & 18 & 36.00 & \multirow{4}{*}{$\begin{array}{c}9.181 / \\
0.027\end{array}$} \\
\hline aged $30-39$ & 55 & 47.01 & 62 & 52.99 & \\
\hline aged $40-49$ & 41 & 41.41 & 58 & 58.59 & \\
\hline aged $\geq 50$ & 31 & 59.62 & 21 & 40.38 & \\
\hline \multicolumn{6}{|l|}{ Marital status } \\
\hline Single & 45 & 60.81 & 29 & 39.19 & \multirow{2}{*}{$\begin{array}{c}4.509 / \\
0.034\end{array}$} \\
\hline Married & 114 & 46.72 & 130 & 53.28 & \\
\hline \multicolumn{6}{|l|}{ Working status } \\
\hline Not working & 63 & 39.13 & 98 & 60.87 & \multirow{2}{*}{$\begin{array}{l}15.411 / \\
<0.001\end{array}$} \\
\hline Working & 96 & 61.15 & 61 & 38.85 & \\
\hline \multicolumn{6}{|l|}{ Educational status } \\
\hline Primary school graduate & 34 & 33.66 & 67 & 66.34 & \multirow{3}{*}{$\begin{array}{c}19.326 \\
<0.001\end{array}$} \\
\hline Middle school graduate & 64 & 52.03 & 59 & 47.97 & \\
\hline$\geq$ University graduate & 69 & 67.65 & 33 & 32.35 & \\
\hline \multicolumn{6}{|l|}{ Breastfeeding status } \\
\hline Breastfeeding & 100 & 46.08 & 117 & 53.92 & \multirow{2}{*}{$\begin{array}{c}4.193 / \\
0.041\end{array}$} \\
\hline Not breastfeeding & 59 & 58.42 & 42 & 41.58 & \\
\hline
\end{tabular}

*Continuity Correction test was used. n: number 
Table 2. Distribution of some risk factors according to groups with and without mastalgia

\begin{tabular}{|c|c|c|c|c|c|}
\hline \multirow{2}{*}{ Risk Factors } & \multicolumn{2}{|c|}{ with mastalgia } & \multicolumn{2}{|c|}{ without mastalgia } & \multirow{2}{*}{ Test $/ p$} \\
\hline & $\mathbf{n}$ & $\%$ & $\mathbf{n}$ & $\%$ & \\
\hline \multicolumn{6}{|l|}{ Use of OCS or HRT } \\
\hline Used (> 6 months) & 10 & 20.83 & 38 & 79.17 & \multirow{3}{*}{$\begin{array}{c}35.558 \\
<0.001\end{array}$} \\
\hline Short-term use & 27 & 35.53 & 49 & 64.47 & \\
\hline Never used & 122 & 62.89 & 72 & 37.11 & \\
\hline \multicolumn{6}{|l|}{ Tea/Coffee consumption } \\
\hline Every day (> 10 cups) & 111 & 50.92 & 107 & 49.08 & \multirow{3}{*}{$\begin{array}{c}1.078 / \\
0.583\end{array}$} \\
\hline Occasionally & 33 & 45.21 & 40 & 54.79 & \\
\hline Never & 15 & 55.56 & 12 & 44.44 & \\
\hline \multicolumn{6}{|l|}{ Smoking } \\
\hline Yes & 60 & 40.27 & 89 & 59.73 & \multirow{2}{*}{$\begin{array}{c}10.621 / \\
0.001\end{array}$} \\
\hline No & 95 & 57.58 & 70 & 42.42 & \\
\hline \multicolumn{6}{|l|}{ Alcohol use } \\
\hline Yes & 7 & 28.00 & 18 & 72.00 & \multirow{2}{*}{$\begin{array}{c}4.341^{*} / \\
0.037 \\
\end{array}$} \\
\hline No & 152 & 51.88 & 141 & 48.12 & \\
\hline \multicolumn{6}{|l|}{ Salt consumption } \\
\hline Very little & 61 & 55.45 & 49 & 44.55 & \multirow{3}{*}{$\begin{array}{c}2.338 / \\
0.311\end{array}$} \\
\hline Consuming iodized salt & 64 & 45.71 & 76 & 54.29 & \\
\hline Excessive salt consumption & 34 & 50.00 & 34 & 50.00 & \\
\hline \multicolumn{6}{|l|}{ Weight gain } \\
\hline Yes & 69 & 41.82 & 96 & 58.18 & \multirow{2}{*}{$\begin{array}{c}9.183 / \\
0.002\end{array}$} \\
\hline No & 90 & 58.82 & 63 & 41.18 & \\
\hline
\end{tabular}

*Continuity Correction test was used. n: number 
Table 3. Distribution of some factors according to groups with and without mastalgia

\begin{tabular}{|c|c|c|c|c|c|}
\hline \multirow{2}{*}{ Risk Factors } & \multicolumn{2}{|c|}{ with mastalgia } & \multicolumn{2}{|c|}{ without mastalgia } & \multirow{2}{*}{ Test $/ p$} \\
\hline & $\mathbf{n}$ & $\%$ & $\mathbf{n}$ & $\%$ & \\
\hline \multicolumn{6}{|l|}{ Preferred type of bra } \\
\hline Tight and small & 49 & 45.79 & 58 & 54.21 & \multirow{3}{*}{$\begin{array}{l}4.200 / \\
0.122\end{array}$} \\
\hline Large and loose & 59 & 58.42 & 42 & 41.58 & \\
\hline Wrapping fully but not tight & 51 & 46.36 & 59 & 53.64 & \\
\hline \multicolumn{6}{|l|}{ Lying on the breast } \\
\hline Yes & 77 & 43.50 & 100 & 56.50 & \multirow{2}{*}{$\begin{array}{c}6.740 / \\
0.009 \\
\end{array}$} \\
\hline No & 82 & 58.16 & 59 & 41.84 & \\
\hline \multicolumn{6}{|l|}{ Taking a blow to the breast } \\
\hline Yes & 13 & 46.43 & 15 & 53.57 & \multirow{2}{*}{$\begin{array}{c}0.039 * / \\
0.843\end{array}$} \\
\hline No & 146 & 50.34 & 144 & 49.66 & \\
\hline \multicolumn{6}{|l|}{ Self-examination method } \\
\hline $\begin{array}{l}\text { Squeezing and looking if something is } \\
\text { there }\end{array}$ & 44 & 35.48 & 80 & 64.52 & \multirow{2}{*}{$\begin{array}{l}17.132 / \\
<0.001\end{array}$} \\
\hline $\begin{array}{l}\text { Examining clockwise without squeezing } \\
\text { to tightly }\end{array}$ & 115 & 59.28 & 79 & 40.72 & \\
\hline \multicolumn{6}{|l|}{ Presence of breast discomfort } \\
\hline Yes & 23 & 17.29 & 110 & 82.71 & \multirow{2}{*}{$\begin{array}{l}95.587^{*} / \\
<0.001\end{array}$} \\
\hline No & 136 & 73.51 & 49 & 26.49 & \\
\hline
\end{tabular}

*Continuity Correction test was used. n: number 
Table 4. Statistical analysis of some risk factors associated with breast pain according to logistic regression

\begin{tabular}{|c|c|c|c|c|c|c|}
\hline \multirow{2}{*}{\begin{tabular}{|l|} 
\\
Risk Factors
\end{tabular}} & \multirow[b]{2}{*}{$\boldsymbol{B}$} & \multirow[b]{2}{*}{ SE } & \multirow[b]{2}{*}{$p$} & \multirow[b]{2}{*}{$\mathbf{O R}$} & \multicolumn{2}{|c|}{$95 \%$ CI } \\
\hline & & & & & Lower & Upper \\
\hline \multicolumn{7}{|l|}{ Age group } \\
\hline aged $30-39$ vs aged $\leq 29$ & -0.060 & 0.487 & 0.902 & 0.94 & 0.36 & 2.44 \\
\hline aged $40-49$ vs aged $\leq 29$ & 0.505 & 0.533 & 0.344 & 1.66 & 0.58 & 4.71 \\
\hline aged $\geq 50$ vs aged $\leq 29$ & 1.252 & 0.587 & 0.033 & 3.50 & 3.50 & 11.06 \\
\hline \multicolumn{7}{|l|}{ Breastfeeding } \\
\hline breast-feeder vs non-breast-feeder & 0.981 & 0.382 & 0.010 & 2.67 & 1.26 & 5.64 \\
\hline \multicolumn{7}{|l|}{ Use of OCS or HRT } \\
\hline Short-term use vs no OCS use & -1.552 & 0.349 & $<0.001$ & 0.21 & 0.10 & 0.45 \\
\hline OCS use vs no OCS use & -1.810 & 0.509 & $<0.001$ & 0.16 & 0.06 & 0.44 \\
\hline \multicolumn{7}{|l|}{ Smoking } \\
\hline Smokers vs non-smokers & 0.903 & 0.324 & 0.005 & 2.47 & 1.31 & 4.66 \\
\hline \multicolumn{7}{|l|}{ Alcohol consumption } \\
\hline drinkers vs non-drinkers & 1.494 & 0.593 & 0.012 & 4.47 & 1.39 & 14.24 \\
\hline \multicolumn{7}{|l|}{ Weight gain } \\
\hline $\begin{array}{l}\text { women who gained weight vs } \\
\text { women who did not }\end{array}$ & 0.953 & 0.316 & 0.003 & 2.59 & 1.40 & 4.82 \\
\hline \multicolumn{7}{|l|}{ Presence of breast discomfort } \\
\hline yes vs no & 3.044 & 0.361 & $<0.001$ & 21.00 & 10.34 & 42.62 \\
\hline
\end{tabular}

Pseudo (Nagelkerke) $R^{2}=0.549$, Hosmer-Lemeshow $\chi^{2}=271,926 p=0.046$

Dependent variable: 1 , mastalgia absent; 0 mastalgia present

Abbreviations: CI, confidence interval; OR, odds ratio; SE, standard error

\section{Discussion}

It was determined that the mastalgia of $48.41 \%$ of the women, who participated in our study, was due to the menstrual cycle. In previous studies, mastalgia rates ranged from $34.4 \%$ to $81 \% .1,15,17$ of the women participating in the study, $21.7 \%$ stated that breast pain limited their daily life activities and $22.6 \%$ said that breast pain caused them to wake up while sleeping. In previous studies, these rates were reported as $25.4 \%$ 28\% and 38\%-43\%, respectively. ${ }^{15,17}$ Mastalgia was significantly higher in women, who were diagnosed with a mass in their breast. Of the patients with mastalgia (133) 83.6\% had masses, diagnosed with radiological 
imaging methods. Of these patients (80) 50.31\% had a fibrocystic disease, (18) 11.3\% duct ectasia, (16) 10.06\% fibroadenoma, (9) 5.66\% simple cysts, (7) 4.4\% intramammary lymph node and (3) 1.9\% complex cysts. In the present study, fibrocystic disease was found in all women that experienced breast pain affecting their daily life activities. USG control, cytological examination, and biopsy are recommended at 4-6 months intervals in patients with breast masses, especially in patients with complicated cysts. ${ }^{18}$

In this study, mastalgia was found to be higher in women aged 30-49, which is consistent with the literature. ${ }^{3}$ It was also determined that women, who were married, not working and primary school graduates had significantly higher mastalgia complaints. Similar to our study, a previous study reported that married or divorced women had complaints more of mastalgia, and contrary to our study, mastalgia complaints were higher in women with graduated from the university. ${ }^{12}$ In another study conducted in our country, it was reported that mastalgia complaints increased in women with low educational status, which is similar to our study. ${ }^{19}$ Upon examining surveys of primary school graduates it was determined that most of them had a fear of getting breast cancer. Of these patients, these who requested were taught how to conduct a breast selfexamination and were informed about breast cancer. Afterward, when patients were reported to have no masses that could indicate breast cancer by radiographic imaging, it was found that mastalgia perception decreased in the majority of patients (81\%). Similarly to our findings, it has been reported that most patients thought that there is no need for a medication to alleviate the breast pain after a physical examination and radiological imaging have ruled out breast cancer. ${ }^{16,20}$

Breast pain has been reported more frequently in women who breastfeed due to improper breastfeeding technique, nipple wounds and infections, mastitis and breast abscess, and the importance of breastfeeding training has been reported. ${ }^{21,22}$ In our study, mastalgia was more common among women breastfeeding than women who did not. It has been reported that OCS should not be used for more than 6 months in mastalgia patients, that switching to Tibolone in mastalgia patients receiving HRT to reduce the pain and that HRT should be terminated if the pain is not reduced. ${ }^{23}$ It also has been reported that estrogens have proliferative effects on the gland tissue for the epithelium of the mammary gland and that it is a recognized mutagenic factor that increases the risk of developing breast cancer. ${ }^{24}$ In addition, they can also cause fullness and pain in the breasts. In our study, patients who received HRT and OC (> 6 months) had significantly higher complaints of mastalgia than those who did not. However, there are also studies that reported that the use of OC does not have any effect on mastalgia. ${ }^{19}$ It has been reported that women with benign breast diseases such as Duct ectasia, fibrocystic disease, and fibroadenoma experience more mastalgia. ${ }^{11}$ In our study, mastalgia was found to be significantly higher in women with benign breast diseases, which were identified with radiological imaging, than women without benign breast disease. Fat necrosis due to breast trauma and damage to the developing breast can cause mastalgia. If breast self-examination (BSE) is carried out correctly, it is possible to breast disorders can be felt and masses can be revealed. Thus BSE is important for early diagnosis and it does not 
traumatize the breast. It has been reported that the detection of breast pathologies is higher in patients who undergo BSE compared to those who do not. 25

It has also been reported that mastalgia is higher in women who use bra sizes that are small for them than in them who use appropriate bras. ${ }^{15}$ In our study, no effect of bra preference on mastalgia was detected. A significant relationship between gaining weight in the last five years and mastalgia has been reported. ${ }^{15}$ Our results also showed an increase in mastalgia complaints with weight gain. It has been reported that excessive salt consumption causes edema in the breast tissue of women with periodic mastalgia, which on the other hand, increases the pain. Thus it has been suggested that salt consumption should be decreased before the menstruation in order to prevent mastalgia. ${ }^{15}$ However, in our study, no significant correlation was found between excessive salt consumption and mastalgia. To prevent mastalgia, it is recommended to reduce the consumption of alcohol and cigarettes. ${ }^{1,12}$ However, some studies have shown that alcohol consumption does not have an effect on mastalgia. ${ }^{15,19}$ In our study, the prevalence of mastalgia was higher in those who consumed alcohol regularly ( $>1$ day/week) than those who did not. It has been reported that there is a significant relationship between smoking (10 or more cigarettes a day) and mastalgia.11,19 In our study, mastalgia complaints were significantly higher among smoking women. It has also been reported that excessive tea and coffee consumption, which leads to regular caffeine intake, is related to mastalgia. ${ }^{1,23}$ But it has also been reported that tea and coffee consumption does not cause mastalgia and that there is no need for caffeine restriction in the diet. ${ }^{15}$ One study found a relationship between coffee consumption and mastalgia but no relationship between tea consumption and mastalgia. ${ }^{19}$ The coffee consumption of the women participating in our study was not high. But there were women with excessive tea consumption. When comparing women with regularly excessive tea consumption ( $>8$ cups/day) women, who only drank 1-2 cups a day, we could not find any relationship between excessive caffeine consumption and mastalgia.

The limitation of our study was that it was applied to patients who applied to the outpatient clinic in a cross sectional period. For this reason, further studies are needed to determine the risk factors affecting mastalgia in community-based and a larger population.

In this study, it has been revealed that in addition to the factors that cause mastalgia, mastalgia is felt at a high level in women with low education due to fear of breast cancer. It was determined that mastalgia was more commonly seen in women who did not know how to carry out breast self-examination. Most women who were trained for breast cancer and breast self-examination did not need medical treatment for mastalgia. Therefore, physicians in primary health care facilities should educate women about breast cancer and breast selfexamination. 
Acknowledgements: Each author acknowledged the final version of the manuscript and submitted the manuscript for approval.

Disclaimer: None to declare.

Conflict of interest: None to declare.

Funding disclosure: None to declare.

Ethical Consideration: Necessary permission for the study was obtained from Yıldırım Beyazıt University Medical Faculty Clinical Research Ethics Committee (237, decision dated November 28, 2018). After giving the necessary explanation and information to the women participating in the study, written and signed approvals were obtained on the informed consent form. After a short explanation, the survey was started. The data was obtained from the surveys. The research was conducted in accordance with the Helsinki Committee decisions.

Funding Sources: The research was financed by the researchers.

Author Contributions: Dr. Servet Kocaöz conducted surveys, data collection, and analysis. In addition, all authors contributed equally to the writing of the manuscript.

\section{References}

1. Ader DN, Shriver CD. Cyclical mastalgia: prevalence and impact in an outpatient breast clinic sample. J Am Coll Surg. 1997;185(5):466-70.

2. Akdeniz S, Kelsaka E, Güldoğuş F. [Retrospective evaluation of the patients with chronic pain admitted to the algology polyclinic between 2000-2010]. Agri. 2013;25(3):115-22.

3. Goyal A. Breast Pain. Am Fam Physician. 2016;93(10):872-3.

4. Groen JW, Grosfeld S, Bramer WM, Ernst MF, Mullender MM. Cyclic and non-cyclic breast-pain: A systematic review on pain reduction, side effects, and quality of life for various treatments. Eur J Obstet Gynecol Reprod Biol. 2017;219:74-93.

5. Salzman B, Fleegle S, Tully AS. Common breast problems. Am Fam Physician. 2012;86(4):343-9.

6. Genc V, Genc A, Ustuner E, Dusunceli EB, Oztuna D, Bayar S et al. Is there an association between mastalgia and fibromyalgia? Comparing prevalence and symptom severity. Breast. 2011;20(4):314-8.

7. Sen M, Kilic MO, Cemeroglu O, Icen D. Can mastalgia be another somatic symptom in fibromyalgia syndrome? Clinics (Sao Paulo). 2015;70(11):733-7.

8. Stochkendahl MJ, Christensen HW. Chest pain in focal musculoskeletal disorders. Med Clin North Am. 2010;94(2):259-73.

9. Yıldırım AC, Yıldız P, Yıldız M, Kahramanca Ş, Kargıcı H. Mastalgia-Cancer Relationship: A Prospective Study. J Breast Health. 2015;11(2):88-91.

10. Arslan M, Küçükerdem HS, Can H, Tarcan E. Retrospective Analysis of Women with Only Mastalgia. J Breast Health. 2016;12(4):151-4.

11. Eren T, Aslan A, Ozemir IA, Baysal H, Sagiroglu J, Ekinci O, Alimoglu O. Factors Effecting Mastalgia. Breast Care (Basel). 2016;11(3):188-93. 
12. Johnson KM, Bradley KA, Bush K, Gardella C, Dobie DJ, Laya MB. Frequency of mastalgia among women veterans. Association with psychiatric conditions and unexplained pain syndromes. J Gen Intern Med. 2006 Suppl 3:S70-5.

13. Santen RJ, Mansel R. Benign breast disorders. N Engl J Med. 2005;353(3):275-85.

14. Yılmaz EM, Çelik S, Arslan H, Değer D. Relation between Mastalgia and Anxiety in a Region with High Frequency of Posttraumatic Stress Disorder. J Breast Health. 2015;11(2):72-5.

15. Koçoğlu D, Kurşun S, Akın B, Altuntug K. Mastalgia and associated factors: a cross-sectional study. Agri. 2017;29(3):100-8.

16. Smith RL, Pruthi S, Fitzpatrick LA. Evaluation and management of breast pain. Mayo Clin Proc. 2004;79(3):353-72.

17. Carmichael AR, Bashayan O, Nightingale P. Objective analyses of mastalgia in breast clinics: is breast pain questionaire a useful tool in a busy breast clinic? Breast. 2006;15(4):498-502.

18. Uzan C, Seror JY, Seror J. [Management of a breast cystic syndrome: Guidelines]. J Gynecol Obstet Biol Reprod (Paris). 2015;44(10):970-9.

19. İdiz C, Çakır C, Ulusoy Aİ, İdiz UO. The Role of Nutrition in Women with Benign Cyclic Mastalgia: A Case-Control Study. Eur J Breast Health. 2018;14(3):156-9.

20. Millet AV, Dirbas FM. Clinical management of breast pain: a review. Obstet Gynecol Surv. 2002;57(7):451-61.

21. Berens PD. Breast Pain: Engorgement, Nipple Pain, and Mastitis. Clin Obstet Gynecol. 2015;58(4):902-14.

22. Jackson KT, Mantler T, O'Keefe-McCarthy S. Women's Experiences of Breastfeeding-Related Pain. MCN Am J Matern Child Nurs. 2019;44(2):66-72.

23. Goyal A. Breast pain. BMJ Clin Evid. 2011;2011. pii: 0812.

24. Wolski H. [Selected aspects of oral contraception side effects]. Ginekol Pol. 2014;85(12):944-9.

25. Miltenburg DM, Speights VO Jr. Benign breast disease. Obstet Gynecol Clin North Am. 2008;35(2):285-300, ix. 